\title{
The Development of the Austrian Jazz Scene and Its Identity 1960-1980
}

\author{
Christa Bruckner-Haring
}

\section{Introduction}

$\mathrm{I}$ n Austria, a country deeply steeped in music history and famous for composers such as Wolfgang Amadeus Mozart, Joseph Haydn, and Anton Bruckner, jazz was quick to earn a place in the cultural landscape and become an integral part of the local music scene. After the end of World War II, Austria eagerly embraced this previously undesirable, denigrated music. Entertainment venues and jazz clubs rapidly appeared all over the country, hosting newly founded dance orchestras, big bands and small ensembles. The most significant ensemble was the Austrian All Stars (1954-1957), a band playing mainly cool and West Coast jazz. ${ }^{1}$ However, in the late 1950s-mainly for economic reasons - many jazz musicians emigrated from Austria, including role models like Joe Zawinul, Fatty George, and Oscar Klein. Thus, the early 1960s saw the development of a new amateur jazz scene, made up of musicians and ensembles that increasingly developed their own distinct characteristics and styles.

This article examines defining factors that led to the establishment of an independent Austrian jazz scene and identity between 1960 and 1980. These factors include jazz festivals and venues (with a focus on the amateur jazz festivals of the 1960s), Friedrich Gulda's commitment to jazz, Graz as a jazz centre and the institutionalisation of jazz at the Graz Academy of Music in 1965, the role of the Austrian broadcasting network (ORF), and the impact of the Vienna Art Orchestra.

The content of this article is based primarily on results of the HERA-funded, interdisciplinary research project Rhythm Changes: Jazz Cultures and European Identities, which examined inherited traditions and practices of European jazz cultures. ${ }^{2}$ Our sources include archival records, musicological and journalistic texts as well as interviews conducted with members of

1 Members: Hans Salomon (b. 1933, alto saxophone), Karl Drewo (1929-1955, tenor saxophone), Josef Erich 'Joe' Zawinul (1932-2007, piano), Rudolf Hansen (1924-2004, bass), and Victor Plasil (19262009, drums).

2 Rhythm Changes: Jazz Cultures and European Identities was funded by Humanities in the European Research Area (HERA), see 'HERA: Humanities in the European Research Area', accessed 28 October 2017, www.heranet.info. For further information, see 'Rhythm Changes', accessed 28 October 2017, www.rhythmchanges.net. 
different branches of the Austrian jazz scene. Musicians, bandleaders, educators, researchers, festival and venue organisers, agency members, policy makers, and journalists offer further important insights into pertinent aspects and developments during this period that had an influence on Austrian jazz identity. ${ }^{3}$

\section{The amateur jazz festivals and their successors}

After the mass emigration of professional musicians in the late 1950s, an amateur jazz scene emerged in the early 1960s, focusing at first on traditional jazz. In 1962, the Austrian Jazz Federation was founded with the aim of supporting jazz development by establishing venues and creating performance opportunities for jazz musicians. ${ }^{4}$ Initiated by Johann Fritz (b. 1940), who served as president of the Federation from 1962 to 1971, the Österreichisches AmateurJazzfestival was one of the organisation's core projects. Modelled after the amateur jazz festival in Zurich (which had been founded in 1951), and with the help of the Swiss festival organiser André Berner, the Austrian event had 'the primary goal of offering "jazzers" an opportunity to perform, and presenting good jazz to the fans, thus doing great service to two things we all love very much: young people and jazz. ${ }^{5}$

The festival took the form of a competition for amateur jazz bands, with the objective of creating performance opportunities for amateur musicians, fostering young talent, and presenting quality jazz to both enthusiasts and a wider audience. Taking place at a renowned highculture venue - the Great Hall of Vienna's Konzerthaus- the contest was held in March each year from 1962 to $1968 .{ }^{6}$ The competition offered two stylistic categories: 'Old-Time Jazz', and 'Modern Jazz'; in order to ensure high standards among the participants, a qualifying round was held. Only the best-rated old-time groups, modern combos, and big bands were invited to the actual festival in Vienna. ${ }^{7}$ Especially in the early years of the competition, the traditional jazz groups were mainly concentrated in Vienna (e.g. the Printer's Jazzband, the Original Storyville Jazzband, the Barrelhouse Jazzband, the Magnolia Jazzband), whereas the modern jazz groups

3 The full list of interviewees can be found at 'Rhythm Changes: Interviews', accessed 28 October 2017, www.rhythmchanges.net/interviews.

4 A Styrian Jazz Federation was founded in 1963.

5 ' $[. .$.$] in erster Linie soll das österreichische Amateur-Jazzfestival den Zweck verfolgen, den Jazzern$ eine Auftrittsmöglichkeit zu geben, den Fans guten Jazz zu präsentieren und so zwei Dingen, die wir alle sehr lieben, einen großen Dienst zu erweisen: der Jugend und dem Jazz.' N. N., 'Zweites österreichisches Amateur Jazz Festival 1963', Jazz Podium 12, no. 2 (February 1963), Austrian edition, 36. The programmes of these festivals were also published as supplements in the Austrian edition of the German journal Jazz Podium.

6 1. Österreichisches Amateur-Jazifestival: 24-25 March 1962; 2. Österreichisches Amateur-Jaz Zfestival: 9-10 March 1963; 3. Österreichisches Amateur-Jazそfestival: 6-8 March 1964; 4. Österreichisches Amateur-Jaz:festival: 5-7 March 1965; 5. Österreichisches Amateur-Jazafestival mit internationaler Beteiligung: 11-13 March 1966; 6. Österreichisches Amateur-Jaz:jestival mit internationaler Beteiligung: 3-5 March 1967; 7. Österreichisches Amateur-Jazafestival mit internationaler Beteiligung: 23-24 March 1968.

7 For the first festival in 1962, out of 57 band applications, 20 ensembles from Styria, Vienna, Upper Austria, and Tyrol were chosen to participate. 


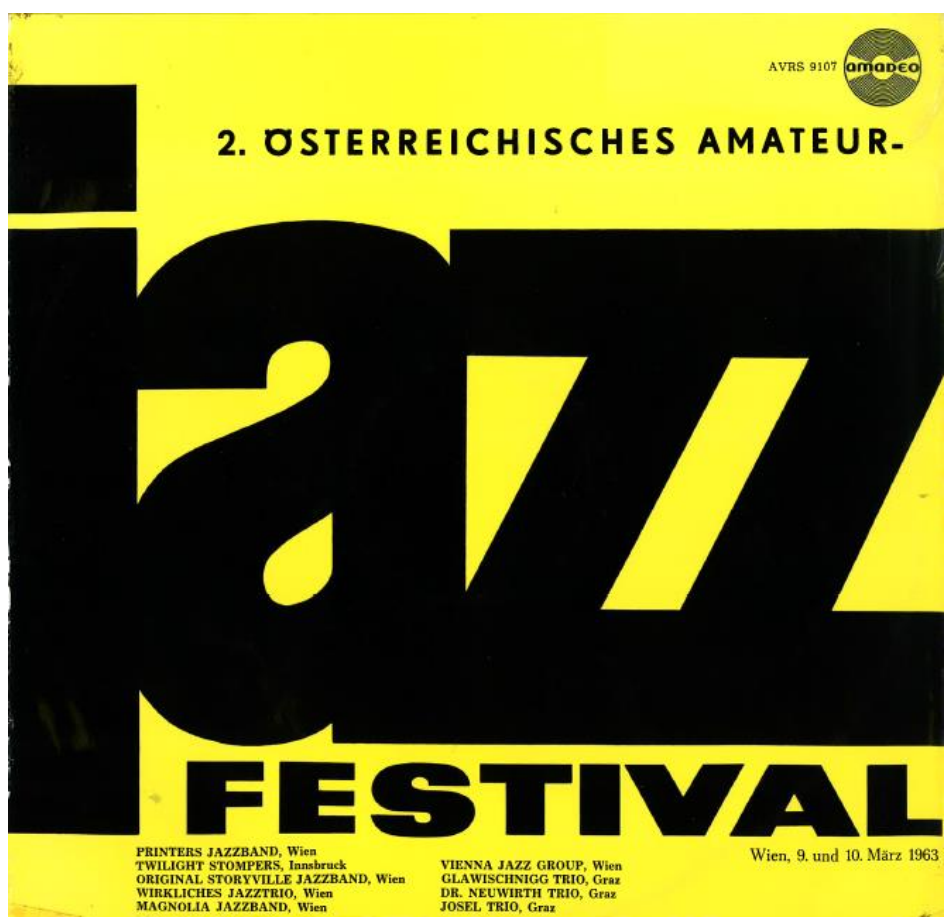

Figure 1: LP cover of the 2. Österreichisches Amateur-Jaz:festival (Amadeo 9107) ${ }^{8}$

often came from Graz (e.g. the Josel Trio, the Modern Jazz Group, the Glawischnig Trio, the Dr. Neuwirth Trio).

The expert jury consisted of jazz critics, journalists, media representatives, educators, organisers, policy makers, and professional jazz musicians. Over time, more professional musicians and international experts were invited as jury members. They evaluated an ensemble's overall impression, its arrangements, musical technique, and improvisation. The prizes ranged from instruments and records to clothing and electronic devices; more importantly, though, the winners were invited to international festivals. Some of the top-ranked performances were also released on $\mathrm{LP}^{9}$

Although these events were supported by public funding, including grants from the Ministry of Education and the Cultural Departments of Vienna and Graz, private sponsorship was also important. The Erste Österreichische Spar-Casse (First Austrian Savings Bank) was a major supporter and took out full-page ads promoting jazz as a music of the young: Young people are enthusiastic about jazz - young people know the value of saving at the First Austrian Savings Bank'. ${ }^{10}$

8 (C) Universal Music GmbH.

9 See 2. Österreichisches Amateur-Jaz:festival (Amadeo AVRS 9107, 1963); and 5. Österreichisches AmateurJaz:festival 1966 (Österreichische Phonothek ÖPh 10001, 1966).

10 'Die Jugend ist begeistert für Jazz - Die Jugend kennt auch den Wert des Sparens bei der Ersten Österreichischen Spar-Casse'. N. N., 'Programm: 6. Österreichisches Amateur-Jazz-Festival', Jazz. Podium 16, no. 2 (February 1967), supplement, III. 


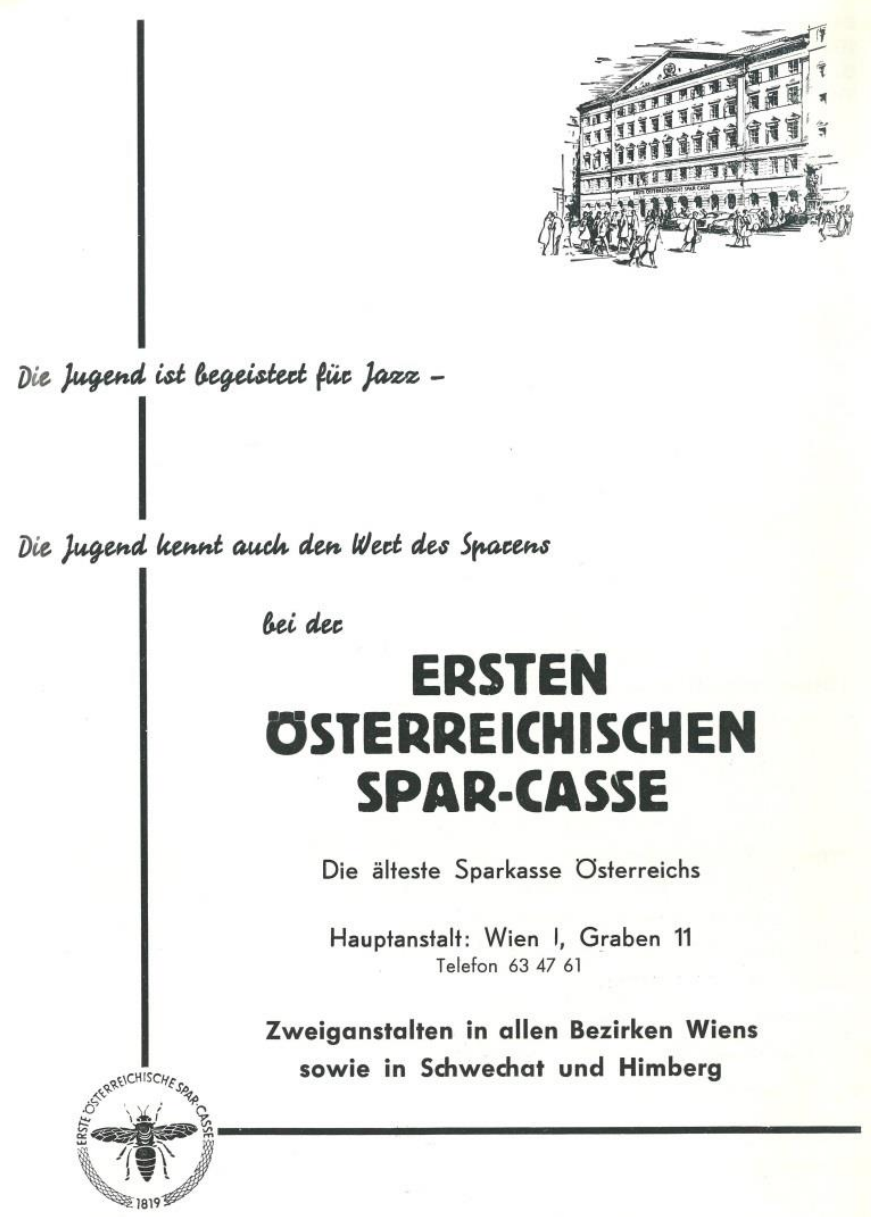

Figure 2: Advertisement of the Erste Österreichische Spar-Casse ${ }^{11}$

Some observers criticised the profusion of advertisements, which appeared not only in the programme booklets but around the entire competition. In an endeavour to justify itself, the organising committee addressed the audience directly in its foreword to the 1964 programme: You will notice a good deal of advertising, both in this extensive programme and repeatedly during the course of the festival. Please remember that without this advertising, without the generous cooperation of understanding companies, the festival would not have been possible. ${ }^{12}$

However, as an established annual event, the Amateur Jazz Festival seemed to have fulfilled its task, supporting the development of jazz in Austria and raising the music's visibility: the events at the Konzerthaus were practically sold out from the very beginning, and the number

11 C Erste Österreichische Spar-Casse / Erste Bank.

12 'Sie werden nicht nur in diesem umfangreichen Programmheft, sondern auch während der Festivals immer wieder viel Werbung finden. Bedenken Sie, bitte, daß ohne diese Werbeleistungen, ohne die großzügige Mitarbeit verständnisvoller Firmen die Durchführung des Festivals nicht möglich gewesen wäre.' N. N., 'Programm: 3. Österreichisches Amateur-Jazz-Festival', Jazz Podium 13, no. 3 (March 1964), supplement, II. 
of participating musicians increased from 124 in 1962 to 231 in $1965 .^{13}$ More importantly, the technique and overall quality of the groups improved over the years, which also led to a wider acceptance of jazz in general. In contrast to the former common practice of imitating American role models, the modern groups in particular developed a greater diversity, experimented musically, and sought new methods of musical creation.

In order to add an international flavour to the competition and to drum up interest for Austrian jazz abroad, foreign groups were invited to the festival as of 1964. This measure proved popular, and in 1966 the phrase 'with international participation' was added to the title of the festival (Österreichisches Amateur-Jazłfestival mit internationaler Beteiligung). The closing concerts featured prominent jazz musicians from abroad, such as the Duke Ellington Orchestra in 1967. Altogether, the Amateur Jazz Festival played a central role in supporting young musicians and their musical activities as well as in promoting the development of jazz in Austria. As Fritz proudly (and accurately) stated in 1968:

'Right now, we are seeing how the development of jazz activities in Austria is thriving. Jazz is enjoying increasing public attention and acclaim, Vienna hosts numerous concerts by the world's best-known groups, jazz fans are finally hearing their music on the radio, jazz clubs are once again becoming more active, and many towns have jazz days or festivals planned this year - all of which is also in accordance with the European trend. ${ }^{14}$

Linked to the successful work of jazz promoters and jazz festivals, jazz venues, offering regular performance opportunities for musicians from Austria and abroad, were established all over the country. The Austrian Jazz Federation, for example, realised its plan to provide performance space in Vienna with clubs like the Josefinum (modern jazz), the Martinschlössl (Swing and Dixieland), and the Storyville Jazzclub (New Orleans jazz). In Krems, Lower Austria, they managed the Erster Kremser Jazzclub; in Innsbruck (Tyrol), it was the Uptown Jazz Saloon—an important meeting point for jazz enthusiasts from the mid-1960s to the mid-1970s. ${ }^{15}$

Due to the improving quality of the ensembles at the jazz festivals, the $8^{\text {th }}$ edition of the Austrian Jazz Federation's Festival, held on March, 15-16, 1969, was billed as a regular international festival-8. Österreichisches Jazafestival mit internationaler Beteiligung — not as a competition, and without its former amateur status. This time, the organisers presented an overview of

13 Johann Fritz, 'Programm: 5. Österreichisches Amateur-Jazz-Festival mit internationaler Beteiligung', Jaz: Podium 15, no. 3 (March 1966), supplement, II.

14 'Dabei erleben wir gerade jetzt eine blühende Entwicklung der Jazzaktivitäten in Österreich. Jazz genießt immer mehr Ansehen und Achtung in der Öffentlichkeit; in Wien gibt es zahlreiche Konzerte der bekanntesten Gruppen aus aller Welt; beim Rundfunkprogramm kommen endlich auch die Jazzfreunde auf ihre Rechnung; Jazzklubs werden wieder aktiver und Jazztage bzw. Festivals sind noch für dieses Jahr an mehreren Orten geplant. Das entspricht dem europäischen Trend.' Johann Fritz, 'Programm: 7. Österreichisches Amateur-Jazz-Festival mit internationaler Beteiligung', Jazz Podium 17, no. 3 (March 1968), supplement, II.

15 The club Jazzland was founded by the subsequent organisation Jazzring Austria in Vienna in 1972. For further information see 'Jazzland', accessed 28 October 2017, www.jazzland.at. 
different contemporary stylistic directions, inviting various established jazz ensembles from Austria and abroad: the main categories were 'Old-Timers' (guest: Curtis Jones), 'A Swinging Parade' (guest: Teddy Wilson Trio), and 'From Modern Jazz to Avant-Garde' (guest: Cannonball Adderley Quintet).

The modern jazz portion, presented in cooperation with the Jeunesse Musicales' jazz concert series, included Vienna's two most progressive free jazz groups: the Reform Art Unit ${ }^{16}$ and the Masters of Unorthodox Jazz. ${ }^{17}$ Scheduled as final performances following the highly acclaimed Cannonball Adderley Quintet, their approach-exploring the possibilities of free improvisation based on the idea of a 'Vienna school of freely improvised music" contrasting reviews from jazz critics and their audience. Anton Michlmayr, the bassist of the Masters of Unorthodox Jazz, recalls: 'There were very conflicting reactions from the audience: a few left demonstratively, whistled and booed; others were excited, very taken [with the performance]. ${ }^{, 19}$ According to the Austrian jazz expert Schulz, the ensembles were 'two extreme groups; at the very least, their fanatic devotion to the execution of their musical ideals must be conceded. ${ }^{20}$ In spite of the generally conservative, sceptical attitude of both scene musicians and audiences, they achieved their national breakthrough soon after their festival performance. In the halls of Vienna's cultural elite, the festival audiences-even in the sold-out concerts-were enthusiastic but reserved and well-behaved, being used to classical concert environments. Antritter found the audience "friendly, averse to any reaction of their own, fairly uninvolved, reserved and well-behaved: in a word, "nice", ${ }^{21}$ and noted that people seemed to be concerned about behaviour inappropriate to classical music venues: if an audience member expressed his enthusiasm too audibly, the indignant looks of his neighbours served to inform him of the impropriety of his action. ${ }^{22}$

16 Founded in 1965; members (as listed in the programme in Jazz Podium 18, no. 3 [March 1969], supplement, $[\mathrm{XX}]$ ): Fritz Novotny (soprano saxophone, flute, Turkish flute, Pakistani oboe), Zdenek Chlum (percussion, vocals, tenor and soprano saxophone), Sepp Mitterbauer (piano, trumpet), Jerzy Ziembrwovsky (bass), Fritz Kotrba (drums, timpani), and Muhammad Malli (percussion, flute).

17 Founded in 1959; members (as listed in the programme, ibid., [XXII]): Harun Barabbas (alto saxophone), Alaeddin Adlernest (bassoon), Ahmad Pechoc (piano), Toni Michlmayr (bass), and Muhammad Malli (percussion).

18 This term was coined by the Masters of Unorthodox Jazz bassist, Anton Michlmayr, connoting an affinity with the chamber music tradition of the Second Viennese School. Andreas Felber, Die Wiener Free-Jazz-Avantgarde: Revolution im Hinterzimmer (Vienna/Cologne/Weimar: Böhlau, 2005), 388-389.

19 'Da waren dann sehr unterschiedliche Reaktionen beim Publikum, ein paar sind ostentativ weggegangen, haben gepfiffen und "Pfuil" geschrien, andere waren begeistert, angetan.' Cited after Felber, Die Wiener Free-Jazz-Avantgarde, 116.

20 '[... zwei extreme Gruppen, denen man zumindest eine fanatische Begeisterung in der Durchsetzung ihres Musizierideals zugestehen muß.' Dietrich Kraner and Klaus Schulz, Jazz. in Austria: Historische Entwicklung und Diskographie des Jazz in Österreich (Graz: Universal Edition, 1972), 26.

21 '[...] freundlich, jeder eigenen Aktion abhold, ziemlich unbeteiligt, reserviert, recht brav, mit einem Wort "liab”". Dieter Antritter, '9. Österreichisches Jazz Festival', Der Jaz:ifreund 12, no. 2 (June 1970), 10-13, here 13.

22 'Machte mal einer im Publikum seiner Begeisterung lautstark Luft, wurde er durch bitterböse Blicke 
In 1970, the Jazz Federation organised two events: the Internationale Wiener Jazztage in March, featuring prominent international guests including the Dizzy Gillespie Quintet, the Dave Pike Set, and the Clarke-Boland Big Band, and the $9^{\text {th }}$ Austrian Jazz Festival, subtitled 'Jazz Jamboree', held in April at the Konzerthaus and the Art Club Amerika-Haus in Vienna. ${ }^{23}$ At the end of 1970, Jeff Grumbach-Palme (1922-1983, pianist and singer) and Erich Kleinschuster (b. 1930, trombonist) founded the association Jazzring Austria, with Palme as its President, which assumed the responsibilities of the Austrian Jazz Federation from 1971 onwards. In 1971 and 1972, a further two-day jazz festival took place, featuring fewer but still internationally renowned acts: ${ }^{24}$ 'today's festival is a service to jazz audiences, a presentation of great, internationally known stars, and a confrontation with new artistic styles. ${ }^{25}$ However, due to economic difficulties, this festival was not repeated.

A further festival that took place in the 1960s was the Internationales Alpenländisches Jarzfestival, first held in Innsbruck in 1964: 'Innsbruck's rich musical life has received new impulses in recent times in the area of jazz. ${ }^{26}$ The fifth Alpine Jazz Festival in 1968 may also have been billed as the first International Dixieland and Jazz. Festival. ${ }^{27}$ Furthermore, the Jazz-Tage, held in Schwaz in Tyrol in the early 1960s, were continued in the 1970s under the name Schwazer September. ${ }^{28}$ The first Internationales Musikforum Ossiachersee, initiated by Friedrich Gulda and held in Carinthia from 30 June to 5 July 1968, took as its motto 'Improvisation in Music: Yesterday, Today, Tomorrow'. The forum included concerts, lectures and discussions. In subsequent years it continued as an international forum with a mixed programme at Stift Viktring on the Wörthersee, featuring prominent musicians such as Fritz Pauer, Ornette Coleman, and Dave Holland.

In the 1970s, the general upswing in the popularity of jazz led to the foundation of more festivals. The Ulrichsberger Kaleidophon was established at the Jazzatelier Ulrichsberg in Upper Austria in 1973 and to this day offers contemporary jazz, classical, and improvised music. ${ }^{29}$ The internationally renowned and successful Jazifest Wiesen, organised by the jazz club of the same

über das Ungebührliche seines Tuns aufgeklärt.' Dieter Antritter, 'Besuch beim Jazz in Österreich', Jazz Podium 19, no. 6 (June 1970), 197-198, here 198.

23 Internationale Wiener Jazそtage: 13-15 March 1970; 9. Österreichisches JazZfestival: Jazz Jamboree: 10-12 April 1970. On the occasion of the Internationale Wiener Jazitage, the European Jazz Federation (founded in 1967; Johann Fritz served as Secretary-General from 1969 to 1972) also held its conference in Vienna.

24 10. Österreichisches Jazz-Festival: 20-21 March 1971; 11. Österreichisches Jaz:festival: 17-18 March 1972. The acts featured at the 11 $11^{\text {th }}$ festival were Art Blakey and His Jazz Messengers, Gerry Mulligan Quartet, and Benny Goodman and His Orchestra.

25 ' [...] so ist das Festival heute ein Dienst am Jazzpublikum, eine Präsentation großer international anerkannter Stars und eine Konfrontation mit neuen künstlerischen Stilbereichen.' N. N, '10. Österreichisches Jazz-Festival', Jazz Podium 20, no. 3 (March 1971), supplement, II.

26 Neue Impulse erhielt das reichhaltige Innsbrucker Musikleben in jüngster Zeit auf dem Gebiet des Jazz'. Jutta Höpfl, 'Erstes Alpenländisches Jazz-Festival in Innsbruck', Amtsblatt der Landeshauptstadt Innsbruck 27, no. 7 (July 1964), 4-5, here 4.

27 Christine Federspiel-Heger, 'Jazz in Tirol', in Musikgeschichte Tirols: Band 3, 20. Jahrbundert, ed. Kurt Drexel and Monika Fink (Innsbruck: Universitätsverlag Wagner, 2008), 579-638, here 605.

28 'Stadtgalerie Schwaz', accessed 28 October 2017, www.stadtgalerieschwaz.at.

29 'Jazzatelier Ulrichsberg', accessed 28 October 2017, www.jazzatelier.at. 
name and featuring modern rock and jazz, was inaugurated in $1976 .{ }^{30}$ Two years later, the international Jazzfestival Saalfelden near Salzburg premiered as 3 Tage Jazz with twelve concerts and international artists such as Irène Schweizer, the Leroy Jenkins Trio, the Cecil Taylor Sextet, and the Vienna Art Orchestra. ${ }^{31}$ Another long-lived festival is the international Musikfest Waidhofen, presenting world, blues, jazz, and folk music; it was first held in Waidhofen an der Thaya (Lower Austria) in 1979. ${ }^{32}$ The festival Konfrontationen, a festival for jazz and new improvised music, began in 1976 with single concerts, took the name Avant-Jazztage in 1978 as it began to focus increasingly on the avant-garde, and was established in its present form in Nickelsdorf in Burgenland in $1980 .^{33}$

\section{Friedrich Gulda's commitment to jazz}

The classical pianist Friedrich Gulda (1930-2000) was interested in jazz from his teenage years onwards. In 1956 he performed at New York's Birdland, where he surprised the audience with a style atypical for a classical musician: a sharp attack, bebop-style single-note phrasing, and a rhythmic sense influenced by cool jazz. ${ }^{34}$ Gulda was an important figure and significantly enriched the domestic jazz scene, both as an active jazz musician and-more importantly-by using his reputation as an acclaimed classical musician and his international contacts to advocate for jazz. In his article 'Jazz und wir' from 1957, Gulda describes jazz as a new, creative, artistically valuable music that has achieved worldwide popularity:

'A music has existed for 50 years that was absolutely new and that continually renews itself, a music that drives musicians to ever higher achievements, that satisfies both those who know it and those who love it, that returns all the values that have been lost in our music to their proper places: phrasing, rhythm, harmony, melody, improvisation, the creative participation of all those involved, the acclaim or rejection of a naive audience, serious criticism, freedom of development, a healthy relationship between supply and demand — for which reason it can exist without subsidies. Last but not least, it has an effect on the listener that is the justification for music itself, or for any art. 35

30 'Wiesen Festivals', accessed 28 October 2017, www.wiesen.at.

'Jazzfestival Saalfelden', accessed 28 October 2017, www.jazzsaalfelden.com.

32 'Folk-Club Waidhofen/Thaya', accessed 28 October 2017, www.folkclub.at.

3 'Jazzgalerie Nickelsdorf', accessed 28 October 2017, www.konfrontationen.at.

4 Published as Live at Birdland (RCA Victor LPM-1355, 1975).

35 'Seit fünfzig Jahren gibt es eine Musik, welche absolut neu war und die sich immer erneuert, welche die Musiker zu immer neuen Höchstleistungen anspornt, welche die Kenner ebenso befriedigt wie die Liebhaber, welche alle verlorengegangenen Werte unserer Musik in ihre ursprünglichen Rechte wieder einsetzt: Phrasierung, Rhythmus, Harmonie, Melodie, Improvisation, schöpferische Betätigung aller Beteiligten, Zustimmung oder Ablehnung seitens eines naiven Publikums, ernsthafte Kritik, freie Entwicklung, gesundes Verhältnis von Angebot und Nachfrage - die daher ohne Subventionen existiert und last not least eine Wirkung auf die Hörer ausübt, die das Dasein der Musik - oder irgendeiner Kunst überhaupt - erst rechtfertigt.' Friedrich Gulda, 'Jazz und wir', Österreichische Musikzeitschrift 12, no. 6 (June 1957), 223-225, here 224. 
Furthermore, acknowledging that this new American music had 'outgrown' European musical development, Gulda encouraged Austria to embrace it. His dedication and passion gave rise to an interest in jazz in the classical music scene and contributed significantly to a general improvement of the status of jazz in Austria.

After having initiated a jazz workshop in Vienna in $1962,{ }^{36}$ Gulda led the EuroJazzorchester from 1964 to 1966, an ensemble that featured Austrian musicians such as Erich Kleinschuster and Rudolf Josel (trombone), Hans Salomon (clarinet), and Joe Zawinul (piano) alongside international soloists such as J. J. Johnson (trombone, USA), Ron Carter (bass, USA), Mel Lewis (drums, USA), Herb Geller (alto saxophone, USA), Pierre Cavalli (guitar, Switzerland), Rolf Ericson (trumpet, flugelhorn, Sweden), and Ronnie Ross (baritone saxophone, India). ${ }^{37} \mathrm{He}$ composed pieces for both the workshop and the Euro-Jazzorchester, including 'The Horn and I' (1962), 'Blue Most' (1962), 'The Veiled Old Land' (1964), and 'Variations for Two Pianos and Band' (1966). The Euro-Jazzorchester became widely acknowledged and performed in classical concert events and venues including the Wiener Festwochen and the Stephaniensaal in Graz under Gulda's leadership. Gulda explains his project and the name 'Euro-Jazz' as follows:

'The name EURO-JAZZ refers not only to the obvious fact that the musicians reside in Europe, but also to the musical, stylistic goals [of the project]. One of my objectives is-instead of remaining stuck in the imitation of American role models—to assimilate the rich material of jazz praxis into the European spirit by reflecting on our own traditions. ${ }^{3} 8$

In 1966, Gulda initiated another important project in Vienna, the Internationaler Wettbewerb für Modernen Jaz: Aiming to provide talented young musicians with a chance to be internationally acknowledged, this modern jazz competition included six instrumental categories-trumpet, trombone, saxophone, piano, bass, and drums. 114 applications were received from over 20 different countries; the age of the applicants ranged from 15 to 25. After a pre-selection at the Vienna Conservatory, 40 musicians were invited to the final round, ${ }^{39}$ giving public concerts at the Vienna Konzerthaus before a jury of jazz stars including Art Farmer, J. J. Johnson, Cannon-

36 Participating musicians: Friedrich Gulda (piano, baritons saxophone, flute), Fatty George (clarinet), Hans Koller (tenor saxophone), Hans Salomon (tenor saxophone), Dick Murphy (trumpet), Erich Kleinschuster (trombone), Robert Politzer (tuba), Hans Rettenbacher (bass), and Viktor Plasil (drums). Friedrich Gulda, Vienna Jazz Workshop (Jazztone J-1259, 1962).

37 Friedrich Gulda, Friedrich Gulda und sein Eurojazz-Orchester (Preiser PR 90667, 1966).

38 'Der Name EURO-JAZZ bezieht sich aber nicht nur auf das äußerliche Faktum des europäischen Wohnsitzes der Beteiligten, sondern auch auf die musikalisch-stilistische Zielsetzung. Ist es doch unter anderem mein Bestreben, nicht in bloßer Nachahmung amerikanischer Vorbilder stecken zu bleiben, sondern durch Besinnung auf unsere eigenen Traditionen den reichen Stoff jazzmäßiger Musikausübung europäischem Geist zu assimilieren.' Friedrich Gulda, 'Zur Einführung', Friedrich Gulda und sein Euro-Jazzorchester [Programme] (Wien, 30 May 1964), 2.

39 Finalists: 9 candidates from the USA, 8 candidates from Czechoslovakia, 5 candidates from the Netherlands, 4 candidates from Germany, 4 candidates from Austria, 3 candidates from Poland, 2 candidates from Brazil, one candidate each from East Germany, Denmark, Sweden, Switzerland, and Yugoslavia. 


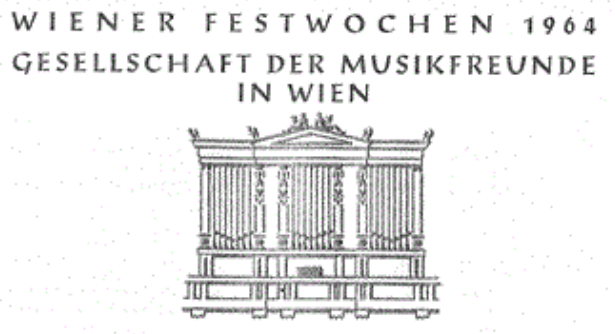

Samstag, 30. Mai 1964

\section{Friedrich Gulda}

und sein

\section{Euro-Jazzorchester}

Figure 3: Programme of the Euro-Jazzorchester, Wiener Festwochen ${ }^{40}$

ball Adderley, Joe Zawinul, Ron Carter, and Mel Lewis. ${ }^{41}$ First and second prizes were awarded in each of the six categories; instead of a second prize for trombone, two second places were awarded in the saxophone category: ${ }^{42}$

\footnotetext{
Trumpet: 1. Franco Ambrosetti (Lugano, Switzerland)

2. Randal Edward Brecker (Philadelphia, USA)

Trombone: 1. Jiggs Whigham (Cleveland, Ohio)

Saxophone: 1. Edward Kenneth Daniels (tenor saxophone; Brooklyn, New York, USA)

2. Lennart Aberg (tenor saxophone; Helsingborg, Sweden)

2. Wlodzimierz Nahorny (alto saxophone; Pradzyn, Poland)

Piano: $\quad$ 1. Fritz Pauer (Vienna, Austria)

2. Jan Hammer (Prague, Czechoslovakia)

Bass: $\quad$ 1. Miroslav Vitous (Prague, Czechoslovakia)

2. Jiri Mraz (Pisek, Czechoslovakia)

Drums: $\quad$ 1. Klaus Weiss (Gevelsberg, Federal Republic of Germany)

2. Manfred Josel (Leibnitz, Austria)
}

40 (C) Gesellschaft der Musikfreunde in Wien, 1964.

41 A concert by the jury members was also recorded as Internationaler Wettbewerb für Modernen Jazz: Jurorenkonzert (Vienna ORF Production, 1966).

42 Karl Gärtner, 'An den Rand geschrieben beim Internationalen Wettbewerb für Modernen Jazz 66', Jaz: Podium 15, no. 6 (June 1966), 163. 


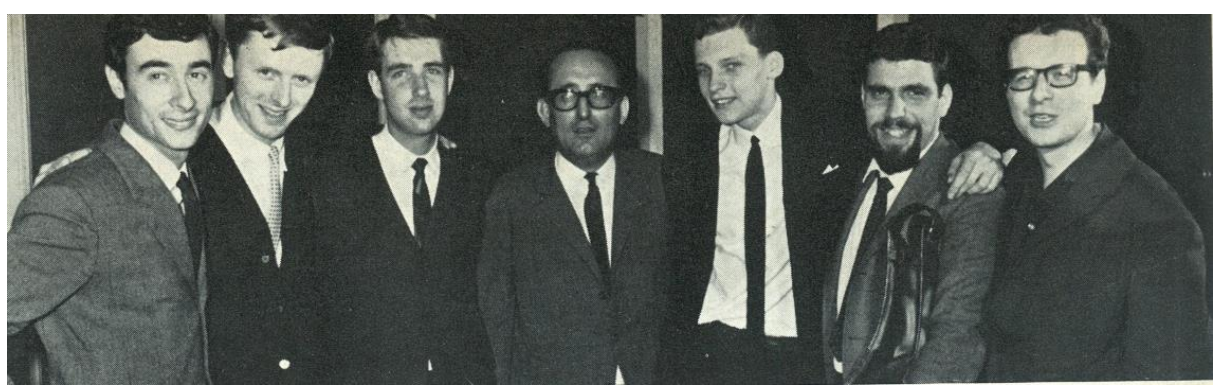

Figure 4: Friedrich Gulda and the winners of the Internationaler Wettbewerb für Modernen Jazz (left to right: Franco Ambrosetti, Klaus Weiss, Jiggs Whigham, Friedrich Gulda, Miroslav Vitous, Edward Kenneth Daniels, Fritz Pauer) ${ }^{43}$

In addition to the prizes and the broadcast of the final concert, ${ }^{44}$ successful participation led to opportunities for study, invitations to international jazz festivals, and international recognition for the musicians, including the Austrian participants Fritz Pauer (1943-2012) and Manfred Josel (b. 1944). The prominence of the jury members and the large number of talented young jazz musicians in Vienna (who also performed in jazz clubs like the Josefinum and Riverboat) transformed the Austrian capital into an international jazz centre for two weeks. According to the General Secretary of the organising committee, Siegmar Bergelt, Gulda wished to raise the international knowledge of jazz in Europe in general but also to increase the acceptance of jazz on a national level. ${ }^{45}$ Zawinul, a jury member, emphasised: 'This competition is a milestone on the way to recognising jazz as a great art form. It brings us closer to our goal: getting this music respected as art by all culturally interested people'. ${ }^{46}$

In the documentary Was ist Jaz?? (1969), ${ }^{47}$ Gulda (introduced as a classical musician and jazz expert) explained the essential musical vocabulary of jazz, including improvisation, chord symbols, formal structures, and melodic, harmonic, and rhythmic characteristics, mainly by comparing them to classical music and offering examples on the piano. He further demonstrated how the European heritage of classical compositional structures could be combined with rhythmic, melodic and harmonic elements of jazz by playing a 'Jazz Toccata' (theme and exposition) with his trio. This was Gulda's individual way—as he put it—of preserving the good and combining it with the new. His impact on the acceptance of jazz as art music became clear

43 C Picture by Georg Paul Günsberg, published in Gärtner, 'An den Rand geschrieben', 163.

44 Published as Internationaler Wettbewerb für Modernen Jaz:. Wien 1966: Schlußkonzert der Preisträger (Amadeo AVRS 9213, 1966).

45 N. N., 'Gulda tritt für Jazz-Nachwuchs ein’, Jazz Podium 15, no. 4 (April 1966), 97-98, here 98.

46 'Dieser Wettbewerb ist ein Meilenstein auf dem Weg der Förderung des Jazz als großer Kunstform, denn er bringt uns dem Ziel näher, daß diese Musikrichtung von allen kulturell interessierten Menschen als Kunst respektiert wird.' N. N. 'Preisrichter und Gastsolisten des Internationalen Wettbewerbes für modernen Jazz in Wien', Jaž Podium 15, no. 5 (May 1966), Austrian edition, 134-138, here 138.

47 Was ist Jaz:? [Documentary], Federal Republic of Germany, 1969. 
in the host's final words, which describe Gulda's work as an audible example of a possible reconciliation of allegedly opposing styles.

\section{Graz as a jazz centre and the institutionalisation of jazz}

An increase in jazz-related activities in Graz led to it emerging as an Austrian jazz centre in the 1950s. The pianist Walter Koschatzky initiated early jazz radio programmes on the Sendegruppe Alpenland; beginning in 1952, Harald Rauter also hosted regular jazz shows on Graz-based radio stations. Lecture series with discussions were also organised by Urania, an educational service institution, to inform a broader audience about jazz (1951-1963). Various jazz bands were founded, including the Serenaders (1950) and the ensembles of the pianist Winfried 'Fridl' Althaller, who also organised ensembles for Radio Graz (e.g. the Kleines Tanzorchester von Radio Graz). ${ }^{48}$ However, after the Stadtpark Café was closed in 1954, jazz musicians lacked a place to meet and perform in Graz. Together with modern artists from other disciplines, these musicians founded the association Vereinigung Forum Stadtpark in 1959 to create a meeting place for all forms of modern art in a renovated building that had previously belonged to the Stadtpark Café. ${ }^{49}$ The Forum Stadtpark officially opened as a venue on November 4, 1960 and included a music department — which, however, was soon divided into 'Kunstmusik' (art music) and 'Jazz' under its head, Friedrich 'Fritz' Körner (b. 1931, trumpet). From the first Jazz Matinée on 20 November 1960 (entitled 'Jazz from Graz'), the Forum Stadtpark served not only as an important performance venue but also represented a home base for jazz life in Graz, a city that soon became a focal point for the burgeoning amateur jazz scene of the $1960 \mathrm{~s}^{50}$

Modern jazz bands emerged as well, some of which were awarded top rankings at the Austrian amateur festivals beginning in 1962, but more importantly provided a creative impetus for the growing jazz scene. Significant musicians and ensembles included the Glawischnig Trio, with the pianist Dieter Glawischnig (b. 1938), the bassist Ewald Oberleitner (b. 1937), and Erich Bachträgl (b. 1944) on drums. They experimented with free jazz in the mid-1960s, using short, pithy themes and free-tonal motives as jumping-off points for dense, dynamic improvisations. According to Oberleitner, 'our colleagues, confronted with new sounds, didn't all take us seriously at the beginning, and the critics were also divided. However, there was a good deal of positive reaction and the fans remained true to us. ${ }^{51}$ Their acceptance grew continuously

48 Manfred Straka, 'Jazz in der Steiermark', Steirische Berichte: Zur Volksbildung und Kulturarbeit 4, no. 7 (July/August 1963), 69-70.

49 Maximilian Hendler, 'Die Jazzszene in Graz 1960-1980', in Kunst und Geisteswissenschaften aus Graz: Werk und Wirken überregional bedeutsamer Künstler und Gelehrter, ed. Karl Acham (Weimar: Böhlau Verlag, 2009), 393-404, here 395-396.

50 Another important jazz venue with regular rehearsal activities and performances was the club Cave 62.

51 'Mit neuen Klängen konfrontiert, wurden wir anfangs nicht von allen Kollegen ganz ernst genommen, und auch die Kritiken waren zwiespältig. Jedoch hatten wir auch viel positive Resonanz und die Fans sind uns treu geblieben.' Ewald Oberleitner, 'Free Jazz in Graz, 1960-1980' (Interview on 19 January 2016). 


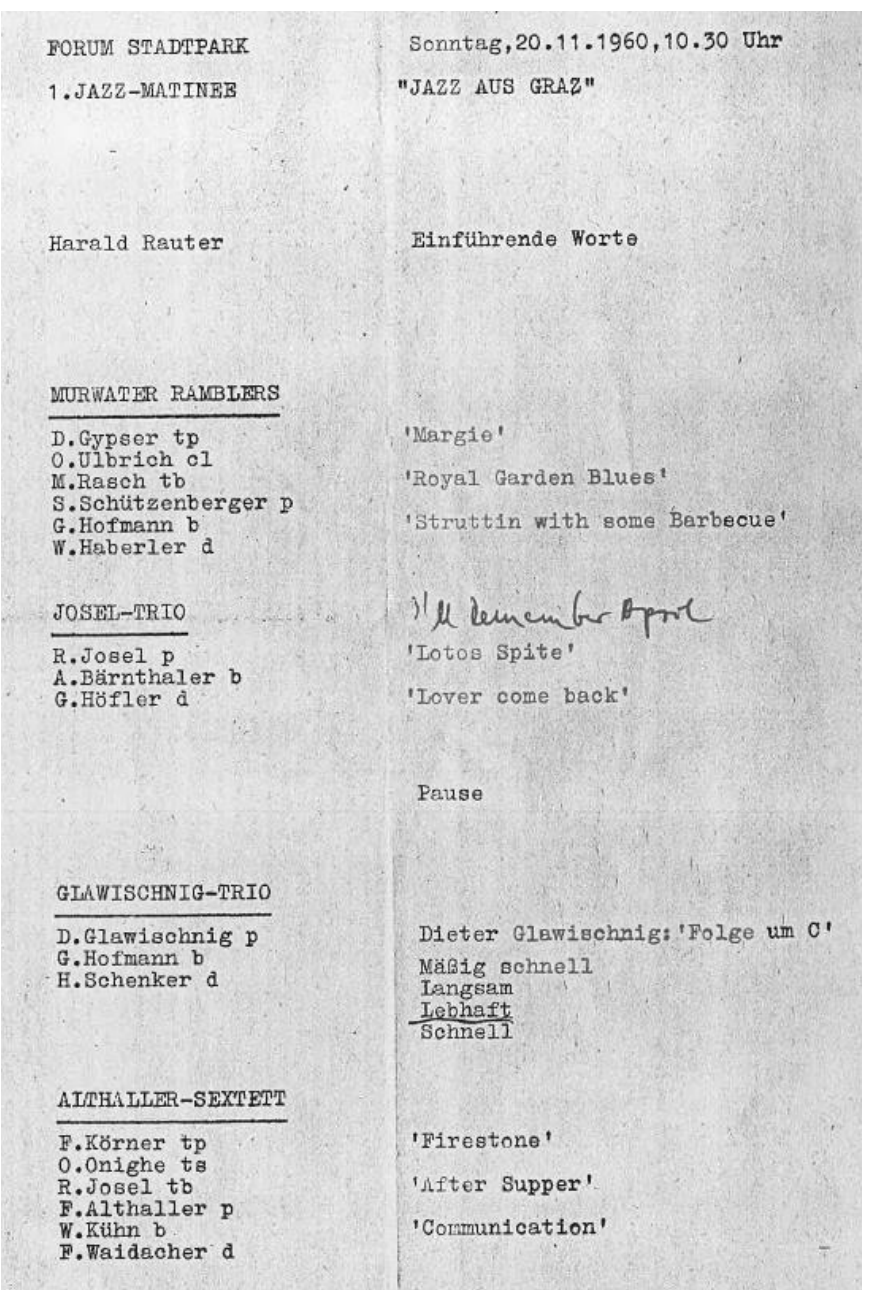

Figure 5: Programme of the $1^{\text {st }}$ Jazz Matinee at the Forum Stadtpark, $1960^{52}$

through the 1970s, and the later trio Neighbours, featuring Glawischnig, Oberleitner and the drummer John Preininger (1947-2002), achieved broad international recognition. Another group, the Josel Trio, was founded in 1960 by the trombonist and pianist Rudolf Josel (b. 1939), with the bassist Anton Bärnthaler (b. 1937) and, after a number of changes, Josel's brother Manfred on drums. Despite their success as one of the leading Austrian jazz formations in the early 1960s, the trio dissolved in 1964 when Rudolf Josel started working with the Vienna Philharmonic Orchestra, reuniting in October 1965 at the first Grazer Jazztage festival. The pianist Harald Neuwirth (b. 1939) was another noteworthy figure. He led both the Neuwirth Triofeaturing the bassist Adelhard Roidinger (b. 1941) and Bachträgl on drums-and the Harald Neuwirth Konsort (whose personnel varied from 1968 onwards). He also composed pieces for the latter group, including a 'Grazer Jazz Mass' (1970). In 1961, Körner founded the New Austrian Big Band. This ensemble was made up of enthusiastic jazz musicians from Graz who were notable for their precise section work and important soloists, including some of the afore-

52 (C) Institute for Jazz Research, Collection Manfred Straka. 
mentioned musicians. Traditional jazz groups were also active in Graz, including the Murwater Ramblers (founded in 1957) and, from the early 1960s onwards, the Royal Garden Jazzband. ${ }^{53}$

The thriving jazz scene, the commitment of individual promoters (particularly Körner), and the support of Friedrich Gulda and the head of the department for music education Friedrich Korčak, led to the founding of the Jazz Institute (Institut für Jazz) in January 1965, at the then Academy for Music and Performing Arts in Graz, with Erich Marckhl as its President. ${ }^{54}$ The initial instructors included Körner (director, trumpet and big band), Dieter Glawischnig (trombone and piano), Manfred Straka (jazz history), Janez Gregorc (arrangement and composition), Harald Neuwirth (piano, jazz improvisation and harmony), Heinz Hönig (woodwinds), Anton Bärnthaler (bass), and Manfred Josel (drums). ${ }^{55}$ In the Institute's early years, the Swedish trombonist Eje Thelin-who also taught there-was a particular draw for students and audiences interested in free jazz (1967-1972). The foundation of Austria's first higher education institution for jazz rapidly cemented the city's status as a jazz centre and has continued to attract international students and to invigorate the regional scene to this day. ${ }^{56}$

Since 1969, as a result of an increasing interest in musicological research, the Institute has hosted regular jazz research conferences in cooperation with the International Society for Jazz Research (founded in 1969 at the Institute's behest). In the course of the Academy's restructuring as a college in 1971, the Jazz Institute was divided into a Jazz Department for practical jazz education and an Institute for Jazz Research. Focusing on historical, cultural and structural-analytical research into jazz and related musical styles, the Institute for Jazz Research now publishes three periodicals: Jaz:forschung/Jazz Research (since 1969, 46 issues), Beiträge zur Jazzforschung/Studies in Jazz. Research (since 1969, 14 issues), and Jazz Research News (since 2000, 52 issues). ${ }^{57}$

In 1968, the Graz-born trombonist Erich Kleinschuster (b. 1930) founded a jazz department at the Vienna Conservatory with instructors Robert Politzer (trumpet), Hans Salomon (saxophone), Fritz Pauer (piano), Rudolf Hanson (bass), and Erich Bachträgl and Walter Grassman (drums). ${ }^{58}$ Since then, jazz departments have been founded at various other music academies too, including the Carinthian State Conservatorium (founded in 1984 by

53 Hendler, 'Die Jazzszene in Graz', 399.

54 Since 1998 University of Music and Performing Arts Graz; for further information see 'Universität für Musik und darstellende Kunst Graz', accessed 28 October 2017, www.kug.ac.at.

55 Elisabeth Kolleritsch, Jazz in Graz: Von den Anfängen nach dem Zweiten Weltkrieg bis zu seiner akademischen Etablierung. Ein zeitgeschichtlicher Beitrag zur Entwicklung des Jazz in Europa (Graz: Akademische Druckund Verlagsanstalt, 1995), 200-201.

56 For further information on the Graz jazz scene and the institutionalisation of jazz in Graz, cf. the contribution by Michael Kahr in this volume (pp. 45-59).

57 For further information, see 'International Society for Jazz Research', accessed 28 October 2017, www.jazzresearch.org; and 'Institute for Jazz Research', accessed 28 October 2017, https://jazzforschung.kug.ac.at.

58 Since 2005 Music and Arts University of the City of Vienna; see 'Musik und Kunst Privatuniversität der Stadt Wien', accessed 28 October 2017, www.muk.ac.at. 


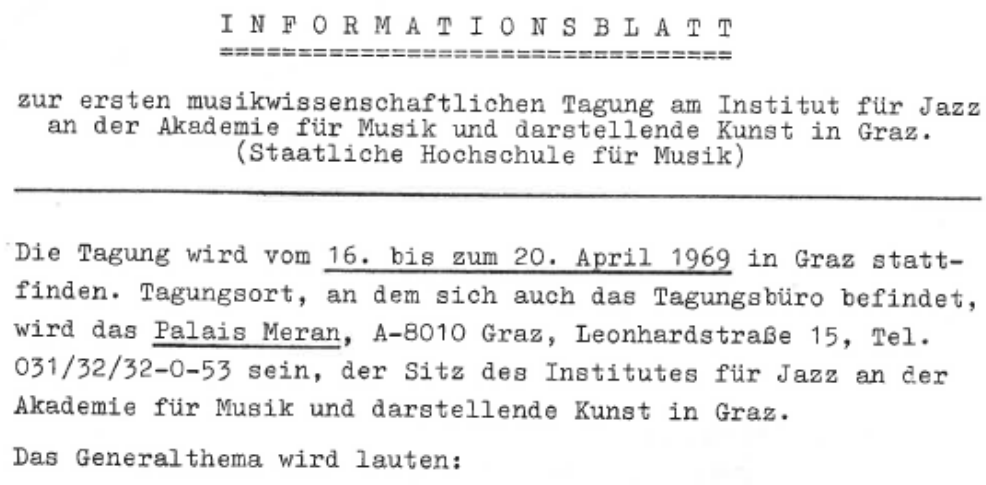

"MUSIKWISSENSCHAFT UND JAZZ"

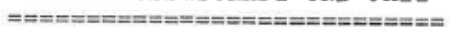

Figure 6: Announcement of the $1^{\text {st }}$ International Jazz Research Conference in Graz ${ }^{59}$

Bachträgl and Kleinschuster) ${ }^{60}$ and the Bruckner Conservatory (now the Anton Bruckner Private University for Music, Drama, and Dance) in Upper Austria (founded in 1989 by the bassist Adelhard Roidinger and the saxophonist Allan Praskin). ${ }^{61}$

Altogether, this institutionalisation has had a tremendous effect on the development of jazz in Austria. In addition to increasing public acceptance, it has produced a large number of well-educated jazz musicians who are both domestically and internationally active. Alumni of these institutions regularly become instructors at music schools and academic institutions themselves, fostering younger generations of musicians and promoting jazz as part of the national musical landscape. ${ }^{62}$

\section{Jazz in Austrian broadcasting}

The 1967 reform of the Österreichischer Rundfunk (Austrian [public] Broadcasting Network, ORF) under its newly elected chairman Gerd Bacher (1925-2015), brought with it an increased role for jazz in radio and television programming. Jazz was granted significantly more prominent airtime during the day, being featured not only in specific jazz programmes but also in general

59 (C) Institute for Jazz Research, Collection Manfred Straka.

60 See 'KONSE: Kärntner Landeskonservatorium', accessed 28 October 2017, www.konse.at.

61 See 'Anton Bruckner Privatuniversität', accessed 28 October 2017, www.bruckneruni.at. For further information on higher jazz education institutions in Austria see Christa Bruckner-Haring, 'Statistical Overview of Jazz in Austria', in Rhythm Changes: Statistical Overviews of Five Partner Countries, ed. Tony Whyton and Christa Bruckner-Haring (Graz: Institute for Jazz Research, University of Music and Performing Arts Graz, 2013), 17-48, here 25-29.

62 For instance, Karlheinz Miklin (b. 1946 in Klagenfurt), a member of the first graduating class in Graz, has achieved international success with his trio (since 1978), his Quinteto Argentina (since 1984), and the Karlheinz Miklin Quartet (various personnel; it has included Ron McClure on bass and Billy Hart on drums). Miklin has also been teaching at the University of Music and Performing Arts in Graz since 1975, and chaired the Jazz Department from 1983 to 2000. See 'Karlheinz Miklin', accessed 28 October 2017, www.miklin.mur.at. 
music shows and as part of informational and sports programming. For the first time, jazz was being presented to a large audience. Jazz music programmes were mainly broadcast together with pop music via the new nationwide entertainment station Ö3-part of the ORF reform conceived by Ernst Grissemann (b. 1934) in an attempt to present more modern, innovative programming.

The most popular and influential host of both radio and TV jazz programmes in the years after 1967 was Walter Richard Langer (1936-1995). Langer had already worked for the $\mathrm{ORF}$ as a news anchor and host of informational programmes (e.g. Zeit im Bild, Zehn vor zehn, Aktuell). He was also an amateur musician and jazz lover, so accepted the offer to host the new radio show Vokal, Instrumental, International (V.I.I.). Langer's goal was to present high-quality entertainment in the programme; he chose the music himself and made ample use of his profound knowledge of different jazz styles. V.I.I. remained on the air for over 20 years (19671987), at first with alternating hosts ${ }^{63}$ from Monday through Saturday (10:05-11:00 until 1971). From 1972 onwards, Langer took over as sole host, broadcasting three shows a week: on Tuesdays he usually introduced new releases, on Thursdays he presented portraits and programmes on modern jazz topics, and Saturdays were devoted to traditional jazz. He ended each show with his trademark line: 'Keep swinging! From 1981, the schedule was reduced to once a week, on Saturdays. Further radio programmes with Langer as host included The Five Faces of Jazz (1968), Jazz Live (1968-1970), Big Band Sound in Stereo (1968-1981), Ö3-Jazzhaus (19811992), Keep Swinging (1987-1988, V.I.I.'s successor), Swing Swing Swing (1988-1990), Jazz Unlimited (1988-1995), Jaz:forum (1989-1995), and Ö1-Jazznacht (1995)..$^{64}$

Langer's TV show Bourbon Street was designed as a TV version of Vocal, Instrumental, International; it was aired for 35 episodes from 1975 to 1979, lasting between 30 and 45 minutes each. In a sophisticated living room setting, Langer, with his distinctive voice and in a serious tone, expounded on different jazz genres, terms and jazz-related topics, often relating them to classical music. He presented musicians, ensembles and musical examples, showing film clips and live festival recordings. He also invited national and international guests into the studio for live performances-Barney Kessel, Albert Mangelsdorff, Art Farmer, Donna Hightower, Werner Pirchner and Harry Pepl were all guests. ${ }^{65}$ Besides his work for the ORF, Langer participated in jazz-related film projects and moderated concerts, he translated books on jazz and wrote liner notes and articles for music journals; he also played guitar and sang in his own music projects. ${ }^{66}$

63 Annemarie Berté, Peter Machac, Hermann Egger, and Walter Richard Langer.

64 'Walter Richard Langer', accessed 28 October 2017, www.members.aon.at/fomalhaut/warila/ wrks.htm; and 'Austria-Forum: Langer, Walter Richard', accessed 28 October 2017, www.austriaforum.org/af/Biographien/Langer $\% 2 \mathrm{C}$ Walter_Richard.

65 The ORF TV show Faces in Jazz was broadcast in 5 episodes in around 1970.

66 'Walter Richard Langer', accessed 28 October 2017, www.members.aon.at/fomalhaut/warila/wrks.htm. 


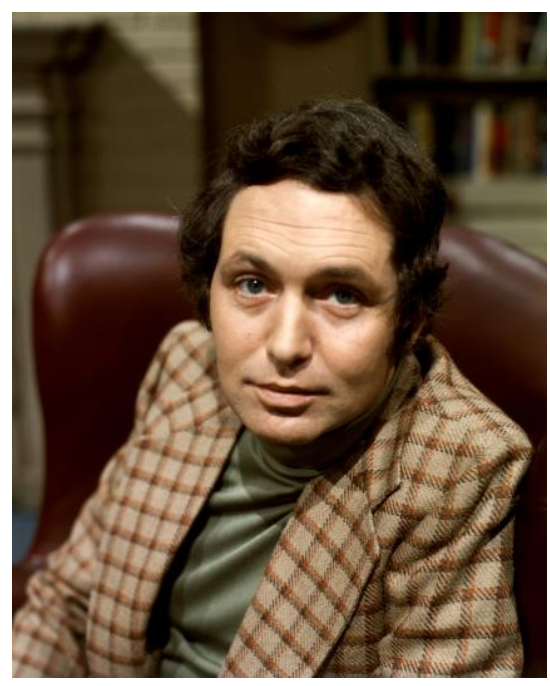

Figure 7: Walter Richard Langer, Bourbon Street ${ }^{7}$

Another important radio host for jazz and related music was Günther 'Howdy' Schifter (19232008), who hosted the popular programme Music Hall on Ö3 beginning in 1968; in the 1980s, the show was renamed Günther Schifters Schellacks and was broadcast on regional radio stations. ${ }^{68}$ In his show, Schifter played examples drawn from his own collection of traditional jazz and swing shellacs, which numbered about 20,000 records. A highly knowledgeable host, he also imparted background and historical information pertaining to the music selections, turning them into entertaining and informative 'history lessons'. In 1978 and 1979, eleven episodes of the programme Schellacksendungen were broadcast on television, where Schifter presented rare recordings and interviewed Austrian jazz musicians. In 1981, the television series Jazz am Samstag introduced renowned international jazz musicians, playing with Austrian colleagues. ${ }^{69}$ Schifter's nickname stems from his country and western music radio programme Western Saloon (since 1968, from 1975-1976 also a TV programme) and his English greeting 'Howdy, friends and neighbours! ${ }^{70}$

The clarinettist and saxophonist Fatty George (b. Franz Georg Pressler, 1927-1982), one of Austria's best-known Dixieland revival and cool jazz musicians, also played a major role in the publicising of jazz in Austria after his return to Vienna in 1967. He moderated the radio shows Jarz Casino and Swing und Dixieland and, from 1977 onwards, also hosted the TV show Fatty Live, where he played viewers' telephone requests live with his band. Altogether, the heightened presence of jazz in radio and television brought the music to a broader audience and resulted in a heightened interest in jazz, notably among young audiences.

67 (C) ORF.

68 Schifter hosted a similar show named Schellack-Sowvenirs for the German broadcaster Bayerischer Rundfunk (channel Bayern 2) until 2003.

69 'Günther Schifter', accessed 28 October 2017, www.wien.gv.at/wiki/index.php/Günther_Schifter.

70 'Howdy! Günther Schifter', accessed 28 October 2017, www.mediathek.at/schifter/der-radiomoderator. 
The augmentation of the ORF's own music productions also supplied work for Austrian jazz musicians. The Erich Kleinschuster Sextet-founded in 1966 and featuring Kleinschuster (trombone), Robert Politzer (1939-2010, trumpet), Hans Salomon (b. 1933, clarinet and saxophone), Rudolf Hansen (b. 1924, bass), Harald Neuwirth (piano), and Erich Bachträgl (drums) ${ }^{71}$ performed mostly hard bop and mainstream jazz. It became one of Austria's best-known jazz ensembles over the subsequent two decades, largely due to its work on ORF productions. ${ }^{72}$ As head producer of ORF radio's popular music department, Kleinschuster founded the ORF Big Band in 1971, drawing core personnel from his sextet and Johannes Fehring's orchestra (b. Johannes Fernbach, 1926-2004). This professional big band was the ORF's flagship band and was used for regular jazz productions on radio and TV (e.g. Jazz. mit Erich Kleinschuster and Big Band Sound in Stereo), performing mainly jazz and pop composed and arranged by Austrian musicians. Kleinschuster managed to sign internationally known artists such as the trumpeter Art Farmer (USA) and the bassist Jimmy Woode (USA) as regular band members; the rhythm section consisted of Fritz Pauer (piano), Harry Pepl (1945-2005, guitar), Woode on bass, and Bachträgl on drums. This top-flight ensemble soon became a stimulating force on the professional jazz scene in Austria and also built an international reputation. Its later leaders included Karel Krautgartner (1922-1982), Ernst Kugler (1923-1985), Johannes Fehring, and Richard Österreicher (b. 1932). ${ }^{73}$ However, despite its positive influence and that of regular jazz programming, the big band was dissolved in 1981. Around the same time, the airtime devoted to jazz was significantly reduced when a survey, initiated by the ORF's Rudolf Klausnitzer, pointed to waning audience interest.

\section{The impact of the Vienna Art Orchestra}

The Vienna Art Orchestra (VAO) and its founder, the Swiss pianist and composer Mathias Rüegg (b. 1952), played a significant role in the development of Austria's independent jazz scene from the late 1970s onwards. After his initial studies and some experience teaching at special schools, Rüegg studied at the (then) Graz Academy of Music from 1973 to 1975 and moved to Vienna in 1976. A year later he founded the VAO, initially called Premier Orchestra d'Art de Vienne. The ensemble soon became known as Europe's most innovative big band, even getting a ranking in the Down Beat Critics' Poll. Rüegg not only led the ensemble but also composed and arranged all the music himself; his work exhibits influences from Impressionism and modern jazz orchestration. The VAO was flexible; the music ranged from hard bop and modal jazz to

71 Occasionally, the ensemble's personnel changed, including Fritz Pauer on piano and Jimmy Woode on bass.

72 See Joe Henderson, Carmell Jones, Clifford Jordan \&o the Erich Kleinschuster Sextet - Volume 1 (Emarcy BVIN01702719, 1968/1969); and Art Farmer, Jimmy Heath, Slide Hampton \& the Erich Kleinschuster Sextet-Volume 2 (Emarcy BSIN02426520, 1968/1971).

73 The discography of the ORF Big Band can be found at 'ORF Big Band Diskographie', accessed 28 October 2017, www.discogs.com/artist/1763938-ORF-Big-Band. 


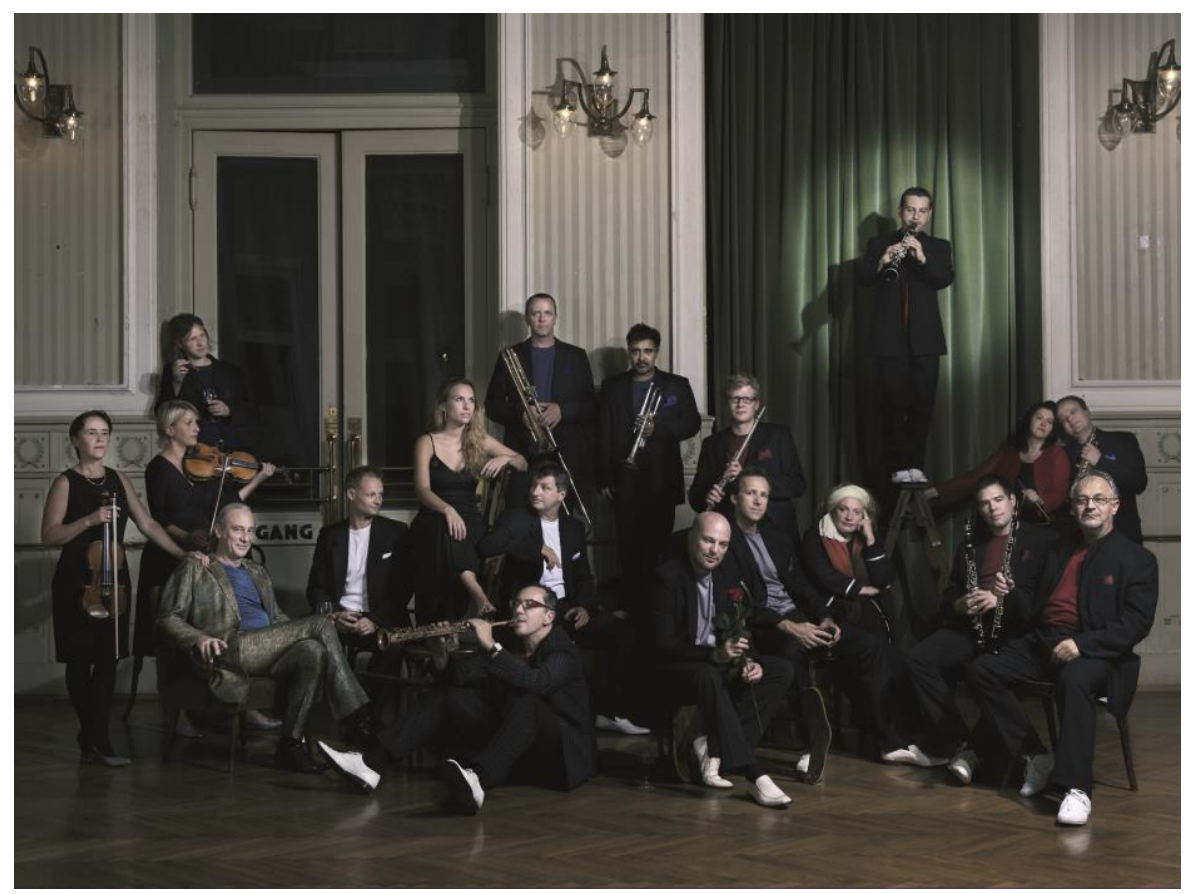

Figure 8: Vienna Art Orchestra ${ }^{74}$

harmonically free jazz, incorporating avant-garde concepts and experimental elements. The orchestra achieved international success with programmes like Concerto Piccolo, ${ }^{75}$ From No Time to Ragtime, ${ }^{76}$ European Songbooke, ${ }^{77}$ A Centenary Journey, ${ }^{78}$ and Art \& Fun. ${ }^{79}$ Rüegg also included folk (e.g. Swiss Swing ${ }^{80}$ ), classical (e.g. From No Art to Mo(z)art, ${ }^{81}$ The Minimalism of Erik Satie ${ }^{82}$ ), and Viennese elements (e.g. All that Strauss $^{83}$ ) in his stylistically varied programmes.

The orchestra was active for three decades and became a magnet for young, talented musicians, many of whom had studied at one of the aforementioned institutions. ${ }^{84} \mathrm{~A}$ large number of these musicians owe their development and at least some of their later recognition to the VAO, including the saxophonist and flautist Wolfgang Puschnig (b. 1956 in Klagenfurt), the Viennese musicians Harry Sokal (b. 1954, saxophone) and Wolfgang Reisinger (b. 1955, drums), and the Styrian trombonist Christian Muthspiel (b. 1962).

74 C Picture by Katsey, www.vao.at.

75 Vienna Art Orchestra, Concerto Piccolo (Hat Hut hat Art CD 6038, 1981).

76 Vienna Art Orchestra, From No Time to Rag Time (Hat Hut hat Art CD 6073, 1983).

77 Vienna Art Orchestra, European Songbook (BMG GIG records 660 177, 1995).

78 Vienna Art Orchestra, A Centenary Journey (Quinton Q0104, 2001).

79 Vienna Art Orchestra, Art \& Fun (Universal Music Emarcy 017 072-2, 2002).

80 Vienna Art Orchestra, Swiss Swing (Moers Music 02060 CD, 1987).

81 Vienna Art Orchestra, From No Art to Mo(z)art (Moers music 02002 CD, 1983).

82 Vienna Art Orchestra, The Minimalism of Erik Satie (Hat Hut hat Art CD 6024, 1984).

83 Vienna Art Orchestra, All that Strauss (TCB 20052, 2000).

84 The VAO was disbanded in July 2010. For a full discography see 'Vienna Art Orchestra', accessed 28 October 2017, www.vao.at. 
Over time, the VAO's success inspired the founding of other jazz orchestras in Austria, their styles ranging from traditional swing to mixtures of contemporary jazz and other art forms. These include the Big Band Süd (founded by Sigi Feigl, 1979; since 1999 known as Jazz Bigband Graz), the Richard Österreicher Big Band (founded in 1981), the Lungau Big Band (founded in 1983 by Horst Hofer), the Austrian Jazz Orchestra (founded by Kleinschuster in 1990), the Upper Austrian Jazz Orchestra (founded in 1991), and the Jazz Orchester Tirol (founded in 2001).

In addition to his work with the VAO, Rüegg supported the national jazz scene by founding the Vienna club Porgy \& Bess ${ }^{85}$ in 1993; Austrian protagonists still considered it the most significant jazz venue in Austria. Christoph Huber joined him soon after and remains the club's artistic director to the present day. Rüegg also initiated the Hans Koller Prize, awarded by the Austrian Music Office (AMO) from 1996 to 2009. ${ }^{86}$

\section{Conclusion}

The period between 1960 and 1980 was vital for the establishment and development of Austria's independent jazz scene. The success of the projects and initiatives discussed here was often linked to the commitment of individuals or organisations and their enthusiasm for jazz.

Starting in 1962, the Amateur Jazz Festival, organised by the Austrian Jazz Federation and its initiator, Johann Fritz, was an important annual forum and performance opportunity for young jazz musicians and enthusiasts. Widespread support and the increasing professionalism of the amateur jazz scene led to the establishment of professional festivals and venues throughout the country, many of which are still important landmarks on the jazz scene today.

Friedrich Gulda was a significant proponent of jazz in Austria: he initiated jazz workshops and festivals, among them the prominent and successful jazz competition in 1966 that did much to position Vienna as an international jazz centre. His influence is felt to this day; younger musicians and active members of the innovative JazzWerkstatt Wien collective, for example, name Gulda's projects as a model for their own work. Moreover, Gulda used his acclaim as a classical musician to advocate for jazz, helping to raise acceptance of the music as an art form, especially among classical musicians and audiences.

Gulda also supported the institutionalisation of jazz at the Academy of Music in Graz in 1965, though it was a large number of musicians and enthusiasts, led by Fritz Körner, who laid the groundwork for the city's development into a national centre of jazz, organising activities for traditionalists and modernists alike. The many highly trained jazz musicians from Austria and elsewhere who have since graduated from domestic music schools have immeasurably enriched the national music scene: today, Austria's superior jazz education opportunities and its many highly skilled, creative musicians are still considered among its greatest strengths.

85 See 'Porgy \& Bess', accessed 28 October 2017, www.porgy.at.

86 'Hans Koller Preis', accessed 28 October 2017, www.hanskollerpreis.at. 
Beginning in 1967, the Austrian broadcasting network, ORF, played a major role in the distribution of jazz to a wider audience. Jazz programming in both radio and television, hosted by moderators like Walter Richard Langer and Günther Schifter, fostered interest in the music, particularly among younger people. Furthermore, Erich Kleinschuster's ORF Big Band provided work for jazz musicians and was an important trendsetter for jazz life in Austria. Since then, however — due to changes in programming and the dissolution of the big band in 1981 — jazz on the airwaves has dwindled, to the chagrin of contemporary musicians.

Finally, the innovative work of Mathias Rüegg and the Vienna Art Orchestra had a great impact on the development of Austrian jazz after 1977. It also served as a springboard for young, talented musicians, who were encouraged to develop their own musical identities.

All these initiatives, projects and personalities contributed to the establishment of a unique and innovative jazz scene in Austria - a scene that has long since found a lasting place in the cultural landscape. 


\section{Figure captions}

- With kind permission by Universal Music GmbH (Fig. 1), Erste Österreichische Spar-Casse/ Erste Bank (Fig. 2), Gesellschaft der Musikfreunde in Wien (Fig. 3), Insitute for Jazz Research, Collection Manfred Straka (Fig. 5 \& 6) and ORF, www.orf.at (Fig. 7).

- Figure 4 by Georg Paul Günsberg, published in Karl Gärtner, 'An den Rand geschrieben beim Internationalen Wettbewerb für Modernen Jazz 66’, Jaž Podium 15, no. 6 (June 1966), 163.

- Figure 8 by Katsey, with kind permission by Vienna Art Orchestra, www.vao.at. 